\title{
C-E Translation of Public Signs in Xi'an TANG Dynasty Cultural Sites from The Perspective of Functional Translation Theory
}

\author{
Ma Qinhua \\ School of Foreign Studies, Xi'an University, 710065
}

\author{
Keywords: Public Signs; C-E translation; Functional Translation Theory
}

\begin{abstract}
Public signs in scenic spots are one of the most important propaganda windows to tourists. Therefore, a proper and accurate translation of public signs is of great importance for the foreigners to get acquainted with Chinese culture, history and civilization. Nevertheless, the translation of public signs in Xi'an is far from standardization. This thesis, based on the previous studies, makes a systematic introduction to the German Functional Translation Theory, and tries to apply it into the C-E translation of public signs and proposes some translation strategies for the purpose of perfecting the translation of public signs. The author of this thesis collects some public signs in Tang Dynasty Cultural Sites and makes an analysis of these signs from the perspective of the German Functional Translation Theory and their existing problems are discussed accordingly.
\end{abstract}

\section{Introduction}

With the blossom of China's tourism, in particular, after its entry into WTO and successfully hosting the 2008 Olympic Games and the 2010 Shanghai World Exposition, an increasing number of foreigners come to China with the hope of enjoying its beautiful scenery, amazing history and mysterious culture. Chinese-English translation of tourism materials plays an indispensable role in their stay in China while traveling or doing businesses. Tourism sign translation aims at helping foreign visitors who speak a different language and live in a different cultural context. From the perspective of Skopostheorie, the overall translation practice was decided by the intended purpose or function of the target text. How can the translator make his translation more readable and acceptable to English-speaking people and make the intended purpose accomplished? In the author's humble opinion, owing to language and cultural differences, the translator needs to do one important preparation before starting his translation, i.e. studying the particular features of Chinese and English tourism sign translation both in content and style, which will be essential for a successful and perfect translation.

\section{Two Functional Translation Theory}

Functional translation theory was born in the time when equivalence was the prevailing translation principle. However, the equivalence can not solve all the translation problems and that 
was why functionalist approach and its main theory, Skopostheorie came into being. The influence of the Skopostheorie can be summarized as follows:

First, the purpose-oriented concept offers more available translation strategies and liberates translation from the conventional word-for-word translation principle. Translation here is not considered as a process of trans-coding, but an act of purpose-driven human action and communication, in which the initiator, translator, user and message receiver interact to achieve a particular purpose. The process of functional translation is more complex.

Second, because the theory demands translators' responsibilities, the role of translators shifts from invisibility to visibility. Because of the theory, translators are no longer passive, but have the chance to display their subjective initiative. In order to fulfill the expected function and meet the expected aim, translators must make suitable decisions to achieve the goal.

Thirdly, as Snell-Homby points out, functionalist approaches are towards cultural rather than linguistic transfer, and they are target-language-culture oriented but not source-language-culture oriented. As a consequence, the needs and expectations of the addressees or receivers of the target text must be taken into account, and the quality of translation is judged by the responses of target receivers, which become the most important yardstick for translation decision.

\section{A Case Study of the Public Sign Translation}

\subsection{Analysis from Cross-Cultural Perspective}

Culture is believed to be the carrier of language. We can not learn a language without knowing its culture.

Tourism translation serves as a tool to propagandize Chinese culture. It covers profound cultural information, such as historical allusion, religious style, horticulture, food culture etc. The principal readers are foreign tourists, and its purpose is to attract them to come to China. This requires the translator to consider the acceptability of the tourists; otherwise the translation may cause misunderstanding or ambiguity. As a consequence, the translation of tourism sign texts should concentrate on the cultural connotation and the acceptability of the translated texts to Western visitors.

Next, we would take some examples in Daming Palace National Heritages Park for analysis. “丹 凤门” is translated as “Dan Feng Gate”; “命妇院” as “Mingfu Courtyard”; “殿中省” as “Dianzhong Ministry”; “麟德殿” as “The Linde Hall”; “玄武门” as“Xuanwu Gate”; “望仙门” as "Wangxian Gate" etc. The translation of these names can not express their culture connotations and also may not meet the requirements of the readers and the tourists. What's worse, they can hardly inspire any reader's or tourist's desire for experiencing the traditional Chinese culture.

Example 1) Source Text: 公元 775 年, 节度使安禄山造反, 迅速破东都洛阳, 向长安逼近, 唐玄宗带领一班朝臣仓皇脱逃。西行至马嵬坡, 随行将士杀死杨国忠, 又逼唐玄宗赐死杨贵 妃。玄宗无奈, 只得忍痛割爱, 命人将杨贵妃勒死, 时年 38 岁。

Target Text: In 755A.D, a military officer, An Lushan, rose up a rebellion. At a short time, the eastern capital Luoyang was captured, and Chang'an, his next prize, was in great danger. Tang Xuanzong took his countries and fled west in great hurry. When they reached Maweipo, the generals and soldiers that had fought all the way with him killed Yang Guozhong, the chancellery, and then they forced Emperor Xuan Zong to order Lady Yang's immediate execution. Helpless and despaired, Xuan Zong had to part, reluctantly, with his favorite. Finally, Lady Yang was hanged at his order.

From the C-E translation of Example 1, it can be noticed that the translator pays more attention to using the cross-cultural awareness. "Yang Guozhong" is translated as "the chancellery", because 
"Yang Guozhong" is the Chancellor of that dynasty. The translator makes the readers understand the Chinese figure by the amplification translation.

\subsection{Analysis from Skopostheorie}

The main principle of Skopostheorie is that the translation skopos will determine translation strategies and approaches. Under the guidance of Skopostheorie, the process of the translation is not decided by the source text or the function's influence to the receiver, but by the predictive function or purpose of the target text. Successful translation is assessed by the extent to which it achieves the intended purpose.

Great priority should be given to the translation of the sign texts for the purpose of the tourism texts. While translating, the information should be adjusted in order to make them better understood from the angle of the tourists. To sum up, sign translation should focus more on expressing information and acceptability.

Example 2) Source Text: 晨风吹来, 丝带轻舞, 脂粉飘香。大唐的贵妇们在父亲、丈夫的陪 同下，报自家姓名，检查门籍、太监引领，按秩序进宫，朝拜皇后。

Target Text: In the morning breeze, the well-dressed ladies were in polished make-up. Accompanied by their fathers and husbands, the ladies reported their names and were inspected of their identities. Led by the eunuch, they enter the palace in order, adoring the empress.

This is one of the signs' commentaries in Daming Palace National Heritages Park. “丝带轻舞”、 “脂粉飘香” are translated “the well-dressed ladies were in polished make-up" by the translator. The translator omitted some Chinese characters, but this does not affect the understanding by the tourists. In the process of the translation, we can infer the difference between Eastern and Western cultures and the acceptability of the tourists. The readers' expectation effects are achieved by using the approach of omission.

From the perspective of Nord, the errors occurred in the process of translation can be divided into four types: linguistic translation errors, misunderstanding of cultural terms, pragmatic translation errors as well as text-specific translation errors. In the following part, the author will concentrate on the specific aspects concerning the texts of the commentaries in Tang Dynasty Cultural Sites.

Linguistic translation errors frequently occur due to the translator's lack of understanding between Chinese and English. Here, the author mainly analyses misspelling, grammatical mistakes, Chinglish, awkward expression and wording.

Misspelling is commonly seen in the C-E translation. Such mistakes have negative effects on tourists' understanding and may spoil the image of the scenic spots.

Example 3) Source Text: 多宝塔感应碑

时代: 唐天宝十一年 (公元 752 年)

撰文: 岑勋 书写: 颜真卿

碑文叙述佛教天台宗僧楚金禅师修建多宝塔的经过，以及唐玄宗资助修塔和派使者吊唁并 监办楚金丧事的情况。书者颜真卿是唐代著名书法家, 京兆万年 (今陕西西安人), 初学褚遂 良, 后从张旭得笔法, 其楷书端庄雄伟, 气势开张, 人称“颜体”。据考, 颜真卿写此碑时四十 四岁, 书体端正, 无一解笔, 历来是学楷书最好的范本, 碑原立唐长安城千福寺 (在今西安西 关), 宋代移存碑林。

Target Text: STONE TABLET OF THE DUOBAO PAGODA

Date: 752 A.D. (The $11^{\text {th }}$ year of Tianbao of the Tangdynasty)

Text: Cen Xun Calligraphy: Yan Zhengqing

The tablet records the process of building the Duobao pagodaby Monk Chu Jin of Buddhist 
Tiantai Sect. Yan Zhenqing was a famous calligrapher of the Tang dynasty, whose regular script gives the impression of the dignity and power, and was called "the Yan style". This handwriting has long been a model for regular script learners.

This example was taken from Forest Stone Museum of Xi'an. We can see there are several spelling mistakes in this translation. "pagodaby" should be corrected as "pagoda by"; "dynasty" as "Dynasty". These spelling mistakes largely detract the attractiveness of the scenic spots.

Grammatical mistakes are another big problem, which will affect the whole target text reception. This kind of mistakes can be avoided through making grammatical contrast between Chinese and English. Meanwhile, if the translator becomes responsible and cautious, this kind of mistakes can be greatly reduced.

Example4) Source Text: 园区导游联络点; 休息区

Target Text: Contact Park Tour Guide Here; Rest Area

This is an example of Chinglish. “园区导游联络点” is translated as “Contact Park Tour Guide Here", which does not conform to the English convention in language expression. The author suggests that it should be revised as “Liaison Here”. “休息区” could be changed into “Lounge”.

Due to the translator's incompetence of English language, culture and the influence of Chinese way of thinking, awkward expressions are unavoidable. In order to avoid making this error, the translator should have a good command of both English and Chinese and be equipped with the knowledge of thinking differences between the Chinese and the English people.

Culture is an important element in the process of translation; we can find that misunderstanding of cultural terms are originated from the conflicts between conventions of the target culture and those of the source culture. The author focuses on the misunderstandings of cultural terms from two aspects: cultural mistranslation and lack of necessary cultural notes.

Example 5) Source Text:善导灵骨塔位于西安市长安区的香积寺内, 建于唐神龙二年 (706)。 唐代高僧善导 (公元 613-681 年) 为净土宗的创始人, 后该宗以善导灵骨塔所在的香积寺为 其祖庭。

Target Text: Shandao Dagoba is located in the xiangji temple, Chang'an District of Xi'an city. The Dagoba was built up in 706 A.D. Because Dharma Master Shandao (613-681A.D) originated Pureland Sect, the sect worshipped the Xiangji temple as the patriarchal court of Pureland Sect.

This is the scenic spot sign commentary in Xiangji Temple in Xi'an. “净土宗” is translated as "Pureland Sect" by the translator, which could not express the religious meaning. So "Pure Land Buddhism" would be more appropriate.

Example 6) Source Text:唐代非常重视儿童的读书写字, 涌现了一批书法巨匠, 如: 初唐楷 书四大家---虞世南, 欧阳询, 褚遂良, 薛稷, 草圣张旭等等。此作品着重表现了唐代儿童刻 苦习字的精神。

Target Text: In the Tang Dynasty, special attention has been given to children practicing handwriting and reading, such social norm has resulted the appearance of lots of great calligraphers, such as the Four Famous Calligraphers of the Early Tang Dynasty, namely Yu Shinan, Ouyang Xun, Chu Suiliang, Xue Ji, who were fond of regular script and Zhang $\mathrm{Xu}$, who was famous for his running script, etc. This illustrates how diligent children are in their calligraphy practice in the Tang Dynasty.

This sign is chosen from Tang Paradise. In the source text, “草圣张旭” is translated as “Zhang $\mathrm{Xu}$, who was famous for his running script". In fact, "running script" symbolizes a typical writing style of Chinese calligraphy, but this phrase can not convey the characteristic of the calligraphic style. The better one might be "cursive style". 


\subsection{Strategies Applicable to C-E Translation of Public Signs}

With regard to the strategies used to tackle the tourism sign translation, they fall into two categories, one can be put up at any tourist destinations, and the other appears only in specified historical sites. When concerning the first category, the existing English translation can be used directly, such as, “游人止步” shouldn't be translated as “Tourists halt” or other versions. "Staff only" is commonly used in English-speaking countries.

Here, the author concentrates on the strategies applicable to the second category, that is, signs appear in the specified historical sites. These signs are translated for the purpose of spreading Chinese culture and giving guidance to the foreign tourists. Therefore, the Chinese characteristics should be preserved along with the English translation.

We all know that the function of the signs is to give tourists information and guidance about the tourism destination. It is especially important for the foreigners as it's a major means for them to have a general understanding about the tourism sites.

Functional translation theories play a significant role in the process of translating. It makes the translation easy to understand. If the English translation could drive home the message which is the criteria to assess a good translation. There are some practical ways applicable in the translation works, such as paraphrase, supplement, analogy, rearrangement and the sentence mood for proper use.

The strategy of supplement is frequently used to add background information to the historical sites. In the introduction of Daming Palace National Heritage Park, the name of “唐太宗李世民” simply as "Emperor Tangtaizong, Li Shimin". Since the opening of this heritage park, thousands of foreign visitors come here for a visit. When I talked with a tourist from England whether he knew Emperor Tangtaizong or not, his response let me down. "I only know he is an emperor, what has happened to him?" As a consequence, the function of this sign did not fully work. For us Chinese, we know who is Emperor Tangtaizong or Li Shimin due to his achievements and great contribution to the Tang Dynasty. What about the foreign tourists? Under such circumstances, supplements are necessary. Besides "Emperor Tangtaizong, Li Shimin", the second emperor of Tang Dynasty who created a prosperity during the "Zhenguan" Period in the Tang Dynasty should be added. In this way, foreign tourists may have a clear picture of the emperor. In the Lady Yang's Tomb, there is a brief introduction about her, “她原为唐玄宗李隆基第十八子寿王李瑁的妃子”. The English version is "She was originally the concubine of Li Mao, the prince and eighteenth son of Li Longji (Emperor Xuan Zong)." In this translation version, the addition "(Emperor Xuan Zong)" is quite necessary.

In English, passive voice is frequently used, which can reach a syntactic convenience in English writing. In the depiction of scenery, passive voice is a better selection. For the effect of cohesion, Chinese active voice is always changed into passive voice in English. For example, “玄武”是镇守 北方的神兽, 是由龟和蛇组合成的一种灵物, 最初对玄武的解释就是乌龟, 龟在古代是长寿 和不死的象征。This sign is translated as “Xuanwu is a mythical animal which guards the north. As a combination of a turtle and snake, Xuanwu is originally interpreted as a turtle, a symbol of longevity in the ancient times.” “唐玄宗时，御史台设置了三院，即台院，殿院和察院。”This sign is translated as "In Emperor Xuanzong's reign of the Tang Dynasty, the Censorate was divided into three parts: Impeachment Court (Taiyuan), Rectification Court (Dianyuan), and Supervision Court (Chayuan)." These are translations collected from Daming Palace National Heritage Park. Passive voice of English version may exert a more natural and idiomatic effect, which might better achieve the purpose of communication.

In the process of translation, there is large space for the translator. We can lengthen or shorten the sentences according to the style of the source text. For instance, “出土的各类人物陶俑, 再现了长 
安城里太平人的生动形象。”. This sign is translated as “The diverse pottery figurines unearthed vividly reproduced the scene of peace and tranquility of people living in Chang'an city". This English translation is too complicated. According to skopos theory, the purpose determines the strategy, we might change it like this, "The diverse and unearthed pottery figurines vividly reproduced the scene of peace and tranquility of people living in Chang'an city.” “神策军是唐代一 支由边防军演变而成的禁军，后逐渐取代原来皇宫卫军的地位。”This sign is translated as "Army of inspired strategy was the imperial army evolved from the frontier guards and gradually took the place of the palace guards in Tang Dynasty." This translation might be rearranged as "Army of inspired strategy was originally the frontier guards and then played the role of guarding the palace in Tang Dynasty." From the example, we could draw the conclusion that through rearrangement, the better effect could be achieved.

\section{Conclusion}

This thesis exemplified and analyzed some bilingual translation versions of public signs in the scenic spots such as in Tang Dynasty Cultural Sites and Daming Palace National Heritage Park under the guidance of the functional theory. The author classified the translation mistakes in order to find the underlying causes. Some findings can be listed as follows:

First of all, the functional theory provides a theoretical basis, i.e. the receiver-oriented perspective, for the C-E translation of tourism texts. When determining the translation strategies and skills, the purpose of translation is an important factor. Therefore, top priority should be given to the functions and receiver-orientation of the tourism texts.

Secondly, it is critically important for the supervision departments to take the right attitude and share the responsibility for the translation. The C-E translation of sign commentaries is of poor quality and prevailing, this phenomenon is mainly due to the negligence and improper management of the supervision departments. So the C-E translation of sign commentaries should be standardized, the sooner, the better. Besides, the supervision departments and language experts should make joint efforts in this aspect. The above findings are believed to be of certain practical significance, yet since this thesis is based on a case study, so the findings may have its limitations. If possible, further studies are expected.

\section{References}

[1] Bullon, Stephen. Longman Dictionary of Contemporary English. Beijing: Foreign Language Teaching and Research Press, 1997

[2] Nord, Christiane. Translating as a Purposeful Activity-Functionalist Approaches Explained. [M]. Shanghai: Shanghai Foreign Language Education Press, 2001:28-29

[3] Nord, Christiane. Text Analysis in Translation-Theory, Methodology, and Didactic Application of a Model for Translation-Oriented Text Analysis. [M]. Beijing: Foreign Language Teaching and Research press, 2006:21-22

[4] Newmark, Peter. Approaches to Translation [M]. Shanghai: Shanghai Foreign Language Education Press, 2001

[5] Newmark, Peter. A Textbook of Translation [M]. Shanghai: Shanghai Foreign Language Education Press, 2001

[6] Nida, Eugene. A. Translating Meaning [M]. California: English Language Institute, 1982:13-16 